\title{
Some Records of Parasitic Worms from Marine Fishes at Plymouth.
}

\author{
By \\ H. A. Baylis, M.A., D.Sc., \\ British Museum (Natural History), \\ and
}

E. Idris Jones, B.Sc.

RECORDS of parasitic worms from British marine fishes are still rather scanty. A good deal of attention has been paid to the subject of the Trematodes by Nicoll, whose valuable list (1915) is indispensable to anyone working in this field. Nicoll is himself responsible for the records of the majority of the 49 species of Trematodes given in the second edition (1931) of the "Plymouth Marine Fauna." The only work done on the Cestodes of fishes at Plymouth appears to have been that of Woodland (1927, a and b), as a result of which 14 species have been placed on record. Very few data are available as to the Nematodes, and none as to the Acanthocephala, of the Plymouth fauna.

During the latter part of May, 1932, the senior author spent some ten days at the Plymouth Laboratory of the Marine Biological Association, collecting parasitic worms from fishes. Over 100 fish were dissected, including representatives of about 40 species. No attempt was made to collect every parasite, including larval forms, but attention was paid almost exclusively to the adult forms living in the alimentary canal or on the gills and external surfaces. The parasites found were simply preserved at once, and were not determined until after the author's return to London.

The hosts were almost all named by Mr. G. A. Steven, of the Laboratory staff, to whom grateful acknowledgment is due for his kind and unfailing help. Mr. Steven suggested that it might be of some interest to record the sizes of the fish found to be infested with parasites. This had not been done during the first day of collecting, but was done regularly thereafter. For all species except skates the measurement given is the length from snout to tip of tail, to the nearest $5 \mathrm{~mm}$. In the case of skates Mr. Steven's usual practice was followed of measuring across the "wings" from tip to tip.

NEW SERIES.-VOL. XVIII. NO. 2. JANUARY, 1933. 
The names here used for the hosts are those used in the "Plymouth Marine Fauna " (second edition, 1931).

The junior author has, at various times, also visited the Laboratory at Plymouth and collected Trematodes from fishes. His identifications are principally from living specimens. In order to avoid the duplication of records, it has been thought desirable to include them all in one list. Both authors, of course, frequently collected the same species from the same hosts, and where this occurred the records given in the subjoined list, unless otherwise indicated, are the senior author's.

The joint list contains 12 species of Trematodes, 4 of Cestodes, 11 of Nematodes, and 2 of Acanthocephala which have not hitherto been included in the "Plymouth Marine Fauna." These are indicated by an asterisk (*). Hosts which are believed to be new for the species in question are indicated by a dagger $(\dagger)$, while a double dagger $(\stackrel{\dagger}{\dagger})$ indicates that the record is the junior author's.

Some of the Nematodes, unfortunately, could not be specifically determined owing to the absence of male specimens or to the incompleteness of the material. The occurrence of the little-known form Ascarophis is of particular interest, and a paper on this Nematode will appear elsewhere. Echinorhynchus leidyi has hitherto been recorded only from "lake trout" in the Great Lakes region of North America. The determination of the specimens from the rockling is therefore open to question, though they appear to agree very closely with the description of $E$. leidyi.

As regards the nomenclature of the parasites recorded, current usage has generally been followed. Two nomenclatural changes have, however, been introduced among the Trematodes, and these call for some explanation.

(1) We have treated the genus Paracotyle Johnstone, 1911, as synonymous with Microbothrium Olsson, 1869, because $P$. canicula, the genotype of Paracotyle, appears to be almost certainly congeneric with $M$. apiculatum, the genotype of Microbothrium. A paper on this form by the junior author will appear elsewhere.

(2) We have substituted the genus Mazocraes Hermann, 1782, for Octobothrium F. S. Leuckart, 1827. It appears to be generally admitted that its genotype, Mazocraes alosa Hermann, is identical with Octobothrium lanceolatum Leuckart, the genotype of Octobothrium. Hence the name Octobothrium must fall into the synonymy of Mazocraes, and there is no justification for retaining the better-known name Octobothrium and treating Mazocraes as a synonym, as has been done by some recent authors.

The junior author has found certain Trematodes which are believed to represent new species. These are not included in the present list, and will be described elsewhere. 
It is a pleasure to acknowledge the kind attention and help which we received at the hands of the Director and staff of the Plymouth Laboratory, and the interest which they took in our work.

\section{LIST OF SPECIES COLLECTED.}

\section{TREMATODA.}

\section{Order Monogenea.}

Fam. Capsalidæ (=Tristomatidæ).

Entobdella solez (v. Ben. and Hesse, 1864). Skin of Solea vulgaris.

\section{Fam. Udonellidæ.}

*Udonella Caligorum Johnston, 1835. Numerous young specimens attached to a Caligus 우 (determined by Dr. I. Gordon as probably C. $\operatorname{rapax}$ M. Edw., 1840) found free in plankton, January 12th, 1932, by Mr. F. S. Russell.

\section{Fam. Monocotylidæ.}

Calicotyle kroyeri Diesing, 1850. Cloaca of Raja maculata.

*Microbothrium [Paracotyle] Canicula (Johnstone, 1911). Skin, on dorsal surface, of †Scyllium canicula.

AcanthoсотуLe SP. Skin of Raja clavata and $\ddagger R$. maculata.

\section{Fam. Polystomatidæ.}

*Onchocotyle appendiculata (Kuhn, 1829). Gills of Raja clavata (26 cm. across), R. blanda (41 cm.), $\$ R$. oxyrhynchus, $\ddagger R$. batis and †Scyllium canicula.

\section{Fam. Octocotylidæ.}

*Mazocraes alos æ Hermann, 1782 (=Octobothrium lanceolatum Leuckart, 1827). Gills of †Clupea finta.

*Mazocraes harengi (v. Ben. and Hesse, 1864). Gills of ††Clupea alosa. Mazocraes scombri (Kuhn, 1829). Gills of Scomber scombrus.

*Dactycotyle denticulata (Olsson, 1876). Gills of $\dagger+$ Merluccius merluccius.

Dactycotyle merlangi (Kuhn, 1829). Gills of †Gadus merlangus.

*Gastrocotyle trachuri v. Ben. and Hesse, 1864. Gills of $\ddagger$ Caranx trachurus.

Axine BeLones Abildgaard, 1794. Gills of §Belone acus (abundant in several specimens). 


\section{Order Digenea.}

\section{Fam. Bucephalidæ.}

Bucephalopsis Gracilescens (Rud., 1819). Stomach and intestine of Lophius piscatorius (in each of 3 specimens); 2 specimens in stomach of †Conger vulgaris (about $3 \mathrm{ft}$.), possibly accidental.

Rhipidocotyle minima (Wagener, 1852). Intestine of Trigla hirundo (24 cm.) and T. cuculus $(24 \mathrm{~cm}$.$) .$

Prosorhynchus aculeatus Odhner, 1904. Stomach, intestine and rectum of Conger vulgaris.

Prosorhynchus Crucibulum (Rud., 1819). Intestine of Conger vulgaris; one immature specimen (?) in intestine of Lophius piscatorius $(47 \mathrm{~cm}$.).

Fam. Fellodistomidæ (=Steringophoridæ).

*Steringophorus fURciger (Olsson, 1868). Immature specimens in stomach and intestine of Pleuronectes limanda (18.5 and $19 \mathrm{~cm}$.$) .$

Steringotrema Cluthense (Nicoll, 1909). Immature specimens in intestine of Pleuronectes microcephalus $(21.5 \mathrm{~cm}$.$) and P$. limanda (18.5 cm.).

Steringotrema Divergens (Rud., 1809). Stomach and intestine of Blennius ocellaris, each of three specimens (12-14 cm.).

\section{Fam. Zoogonidæ.}

*Zoogonus? Rubellus (Olsson, 1868). Immature specimens in intestine of $\uparrow$ Pleuronectes limanda (16 cm.) and $\uparrow$ Labrus mixtus $(27 \mathrm{~cm}$.$) .$

ZoogonoIdes viviparus (Olsson, 1868). Rectum of $\ddagger$ Callionymus lyra and $\ddagger$ Pleuronectes microcephalus; immature specimens in rectum of Pleuronectes platessa (36.5 cm.).

\section{Fam. Allocreadiidæ.}

Podocotyle atomon (Rud., 1802). Intestine of Cottus bubalis.

Podocotyle reflexa (Creplin, 1825). Intestine of Spinachia vulgaris, each of 4 specimens $(12 \cdot 5-16 \mathrm{~cm}$.$) ; intestine of \dagger$ Onos tricirratus.

Podocotyle syngnathi Nicoll, 1913. One specimen in intestine of Entelurus aequoreus (44 cm.).

Lebouria varia Nicoll, 1910. Intestine of Callionymus lyra, †Labrus mixtus (two out of four specimens, ơ $27 \mathrm{~cm}$., ㅇ $21 \mathrm{~cm}$.) and $\dagger \ddagger$ Labrus bergylta.

*Helicometra fasciata (Rud., 1819). Intestine of †Crenilabrus melops. 
Helicometra pulchella (Rud., 1819). Intestine of †Trigla lineata (26 cm.), †tT. hirundo and Serranus cabrilla $(18 \mathrm{~cm}$.$) ; stomach of$ $\ddagger$ Trigla cuculus.

\section{Fam. Azygiidæ.}

Ptychogonimus megastomus (Rud., 1819). Stomach of $\$$ Mustelus vulgaris.

\section{Fam. Hemiuridæ.}

Hemiurus communis Odhner, 1905. Stomach of Molva vulgaris (57 cm.) ; Lophius piscatorius (two out of three specimens); Gadus merlangus (25 cm.) ; Trigla lineata $(26 \mathrm{~cm}$.$) ; †Conger vulgaris (about 3 \mathrm{ft}$.$) ;$ †Cottus scorpius. Usually only one specimen found in each fish, but twelve in C. scorpius.

Lecithochirium rufoviride (Rud., 1819). Stomach of Conger vulgaris: (each of three specimens); stomach of $\$$ Lophius piscatorius.

*Lecithochirium gravidum Looss, 1907. Stomach of Conger vulgaris (each of three specimens).

Lecithaster gibbosus (Rud., 1802). Intestine of †Cepola rubescens (two out of four specimens, 54 and $55 \mathrm{~cm}$.) ; one immature specimen (?) in intestine of Scophthalmus norvegicus $(9 \cdot 5 \mathrm{~cm}$.$) .$

Derogenes varicus (Müller, 1784). Stomach of Gadus merlangus (25 cm.), Merluccius merluccius (27.5 cm.), Trigla hirundo $(29.5 \mathrm{~cm}$.$) ;$ †Trigla cuculus; stomach and intestine of Lophius piscatorius (about $2 \mathrm{ft}$.) ; mouth of $\div$ Cottus bubalis.

Hemipera ovocaudata Nicoll, 1913. Mouth of †ONos mustela and $\dagger$ † tricirratus.

Symaptobothrium caudiporum (Rud., 1819). Stomach of $\dagger$ Rhombus lavis ; stomach of †Conger vulgaris. One specimen (?) in stomach of Trigla hirundo (24 cm.).

*Sterrhurus fusiformis (Lühe, 1901). Stomach of $\dot{t}$ Conger vulgaris ; 'stomach of $\dagger+$ Lophius piscatorius.

Lecithocladium excisum (Rud., 1819). Stomach of $\ddagger$ Scomber scombrus (four in each of two specimens).

\section{CESTODA.}

Order BothriocephaLIDEA.

Fam. Bothriocephalidæ.

*Bothriocephalus scorpiI (Müller, 1776), (=bipunctatus Zed.). Intestine of $\uparrow S c o p h t h a l m u s$ norvegicus $(9 \cdot 5 \mathrm{~cm}),. \uparrow$ Arnoglossus laterna (each of two specimens, 12 and $14 \mathrm{~cm}$.), Cottus bubalis (attached to pyloric cæca); a fragment in stomach of Merluccius merluccius (28 cm.), probably accidental. 


\section{Order Tetrarhynchidea.}

Fam. Tentaculariidæ (=Tetrarhynchidæ).

*Grillotia [Tetrarhynchus] erinaceus (v. Ben., 1858). Spiral valve of Raja clavata.

\section{Order Tanimea.}

\section{Fam. Onchobothriidæ.}

AcanthoвотнRium coronatum (Rud., 1819). Four immature specimens in spiral valve of Scyllium catulus $(46 \mathrm{~cm}$.).

Calliobothrium verticillatum (Rud., 1819). Intestine of $\ddagger$ Mustelus vulgaris.

\section{Fam. Phyllobothriidæ.}

*Phyllobothrium thridax v. Ben., 1850. Spiral valve of Raja clavata and $R$. blanda (41 cm. across).

*Anthobothrium auriculatum (Rud., 1819) of Johnstone, 1906. One specimen in spiral valve of Raja blanda (41 cm. across).

(?) Echeneibothrium tumidulum (Rud., 1819), (=E. variabile v. Ben.). Spiral valve of Raja clavata (one in each of two out of five specimens).

\section{NEIMATODA.}

Order Ascaroidea.

Fam. Ascaridæ.

*Contracecum clavatum (Rud., 1809). Intestine of Conger vulgaris (about $3 \mathrm{ft}$.$) ; stomach of Gadus merlangus (27 cm., 33.5 \mathrm{~cm}$.$) ;$ stomach of Merluccius merluccius $(27.5 \mathrm{~cm}$.) -immature specimens also in stomach and intestine of two other examples $(17.5$ and $28 \mathrm{~cm}$.) ; stomach and intestine of Lophius piscatorius (about $2 \mathrm{ft}$. and $47 \mathrm{~cm}$.) ; stomach of Cottus bubalis ; stomach of Zeus faber (three out of four specimens, $15 \cdot 5-27.5 \mathrm{~cm}$.$) ; intestine of Capros aper (6 \mathrm{~cm}$.$) ;$ intestine [and gill-chamber] of Mullus surmuletus $(22.5 \mathrm{~cm}$.).

*Contrac acum rigidum (Rud., 1809). In tumours in stomach of Lophius piscatorius (two out of three specimens, one $47 \mathrm{~cm}$.).

\section{Order Fillarioidea.}

Fam. Philometridæ (=Dracunculidæ).

*Philometra sp. Females found twice in intestine of Trigla cuculus (22 and $15 \mathrm{~cm}$.$) .$ 


\section{Fam. Spiruridæ.}

*Proleptus obtusus Duj., 1845. Stomach and anterior portion of intestine of Scyllium canicula and S. catulus (every specimen examined).

*Proleptus ? Robustus (v. Ben., 1871). Stomach of Raja clavata (three out of five specimens, 26,28 , and $40 \mathrm{~cm}$. across).

\section{Fam. Cucullanidæ.}

*Cucullanus heterochrous Rud., 1802. Intestine and rectum of Pleuronectes platessa (two out of three specimens, 26 and $27.5 \mathrm{~cm}$.) ; intestine of Solea vulgaris (one out of three specimens, $39.5 \mathrm{~cm}$.).

*Cucullanus hians (Duj., 1845). Intestine of Conger vulgaris (each of three specimens); one specimen in intestine of Lophius piscatorius (47 cm.).

*Cucullanus sp. Intestine of $\ddagger$ Mullus surmuletus.

\section{Fam. Incert.}

*Ascarophis ? morrhue v. Beneden, 1871. Two female specimens in stomach of $\dagger$ Trigla lineata $(26 \mathrm{~cm}$.$) .$

\section{Order Trichinelloidea.}

\section{Fam. Trichinellidæ.}

*Capillaria sp. One female specimen in spiral valve of Scyllium catulus $(46 \mathrm{~cm}$.$) .$

*Capillaria sp. Two immature females in rectum of Pleuronectes platessa $(26 \mathrm{~cm}$.$) .$

\section{ACANTHOCEPHALA.}

Fam. Echinorhynchidæ.

*Echinorhynchus gadi Zoega, in Müller, 1776. One specimen in intestine of $\dagger$ Spinachia vulgaris (one out of four specimens).

*Echinorhynchus ? Leidyi Van Cleave, 1924. A pair of specimens in intestine of $\dagger$ Onos mustela. 


\section{REFERENCES.}

Nicoll, W. 1915. A List of the Trematode Parasites of British Marine Fishes. Parasitol. VII, pp. 339-378.

Woodland, W. N. F. 1927a. On Dinobothrium septaria van Beneden 1889, and Parabothrium bulbiferum Nybelin 1922. Journ. Parasitol. XIII, pp. 231-248, Pls. XII, XIII.

Woodland, W. N. F. 1927b. A Revised Classification of the Tetraphyllidean Cestoda, with descriptions of some Phyllobothriidæ from Plymouth. Proc. Zool. Soc. Lond., Pt. 3, pp. 519-548, Pls. I-V. 